\title{
Excess aldosterone as a mechanism of resistant salt- sensitive arterial hypertension
}

Citation for published version (APA):

Torresan, F. (2022). Excess aldosterone as a mechanism of resistant salt-sensitive arterial hypertension. [Doctoral Thesis, Maastricht University]. Maastricht University. https://doi.org/10.26481/dis.20220221ft

Document status and date:

Published: 01/01/2022

DOI:

10.26481/dis.20220221ft

Document Version:

Publisher's PDF, also known as Version of record

\section{Please check the document version of this publication:}

- A submitted manuscript is the version of the article upon submission and before peer-review. There can be important differences between the submitted version and the official published version of record.

People interested in the research are advised to contact the author for the final version of the publication, or visit the DOI to the publisher's website.

- The final author version and the galley proof are versions of the publication after peer review.

- The final published version features the final layout of the paper including the volume, issue and page numbers.

Link to publication

\footnotetext{
General rights rights.

- You may freely distribute the URL identifying the publication in the public portal. please follow below link for the End User Agreement:

www.umlib.nl/taverne-license

Take down policy

If you believe that this document breaches copyright please contact us at:

repository@maastrichtuniversity.nl

providing details and we will investigate your claim.
}

Copyright and moral rights for the publications made accessible in the public portal are retained by the authors and/or other copyright owners and it is a condition of accessing publications that users recognise and abide by the legal requirements associated with these

- Users may download and print one copy of any publication from the public portal for the purpose of private study or research.

- You may not further distribute the material or use it for any profit-making activity or commercial gain

If the publication is distributed under the terms of Article $25 \mathrm{fa}$ of the Dutch Copyright Act, indicated by the "Taverne" license above, 


\section{SUMMARY}

CHAPTER 1 provides an introduction for this thesis in which the relevance of adequate blood pressure (BP) control is discussed. The screening for secondary causes of arterial hypertension (HT) is mandatory since it allows i) the identification of the underlying HT pathophysiology ii) cure of HT or a significant improvement of BP control and iii) a better prevention of target-organ damage and cardiovascular events by a specific pharmacological treatment.

Primary aldosteronism (PA) is the most common and potentially curable cause of HT and it should always be suspected in hypertensive patients. The diagnosis of PA and its targeted treatment are of crucial importance since aldosterone excess, independently from the degree of BP, induces fibrosis, generation of reactive oxygen species, and inflammatory changes; patients with PA have higher cardiovascular morbidity and mortality than ageand sex-matched patients with essential HT and the same degree of BP elevation. Subtyping of PA should be performed at third level referral centers that can adequately perform and interpret adrenal vein sampling (AVS) results. When a unilateral cause of PA is discovered, hyperaldosteronism and hypokalemia are curable with adrenalectomy in almost all patients, and BP can be normalized or considerably reduced in a substantial proportion of the patients. Screening for PA is particularly beneficial when HT is severe and/or resistant to treatment, because target treatment and/or surgery allow to bring blood pressure under control and the withdrawal, or a prominent reduction in the number and dosage of antihypertensive medications, and permit to prevent or regress organ damage.

Finally, the current views on the physiology of sodium $\left(\mathrm{Na}^{+}\right)$homeostasis and BP have been discussed. High $\mathrm{Na}^{+}$intake is causally related to high BP and high BP is known to increase the risk for cardiovascular events and death considerably. The effect of $\mathrm{Na}^{+}$intake on BP varies considerably among individuals, discriminating sodium sensitive individuals, who are characterized by a BP increase after an increase in $\mathrm{Na}^{+}$intake, from $\mathrm{Na}^{+}$resistant individuals, who do not develop a BP increase. According to the two-compartment model, the kidney is solely responsible for matching $\mathrm{Na}^{+}$excretion and $\mathrm{Na}^{+}$intake, thereby preventing $\mathrm{Na}^{+}$and water retention, extracellular volume expansion and an increase in BP. The kidney is therefore thought to play a pivotal role in determining the effects of $\mathrm{Na}^{+}$ intake on BP (i.e. $\mathrm{Na}^{+}$sensitivity).

This theory has been questioned by long-term $\mathrm{Na}^{+}$balance studies that have shown that $\mathrm{Na}^{+}$can accumulate in the human body without concurrent retention of water. This is not 
in line with the current physiological concept that $\mathrm{Na}^{+}$retention is always accompanied by water retention. Experimental studies have demonstrated that negatively-charged polysaccharides, called glycosaminoglycans (GAGs), are able to bind and osmotically inactivate $\mathrm{Na}^{+}$in the skin interstitium. As a result, $\mathrm{Na}^{+}$storage by GAGs will not be accompanied by water retention. Skin $\mathrm{Na}^{+}$accumulation has been observed in patients that are prone to volume expansion such as patients with HT, hyperaldosteronism and dialysis patients and may affect BP regulation.

In CHAPTER 2 we have investigated if AVS, the key test recommended by current guidelines to demonstrate a unilateral surgically curable form of PA, can identify PA even in resistant hypertensive patients $(\mathrm{RH})$, who by definition are on multiple drugs. Moreover, we sought for determining if AVS-guided adrenalectomy can be useful to resolve BP resistance to treatment in these patients. We identified 77 patients with RH and additional clues of PA among 1016 consecutive patients referred for "difficult-to-treat" hypertension to our ESH Center of Excellence. As they wished to pursue surgical cure of PA, they underwent AVS, which showed unilateral PA in 25 patients; these 25 patients were submitted to AVS-guided laparoscopic unilateral adrenalectomy. After surgery, BP fell from $161 / 99 \pm 26 / 14 \mathrm{mmHg}$ at baseline, to $133 / 84 \pm 14 / 9 \mathrm{mmHg}$ at 6 months $\left(\mathrm{p}<10^{-4}\right.$ and $\mathrm{p}=10^{-2}$, for systolic and diastolic, respectively), notwithstanding the fall of antihypertensive drugs required to achieve blood pressure control (from 3.6 \pm 0.2 agents at baseline to $1.2 \pm 0.2$ at 6 months; and from $4.8 \pm 2.1$ to $1.2 \pm 1.4$ defined daily doses; $\mathrm{p}<10^{-4}$ for both). RH was resolved in all and $20 \%$ of the patients were clinically cured in that they no longer needed antihypertensive treatment; moreover, $96 \%$ were biochemically cured and cardiac and renal organ damage regressed. Together, these data demonstrate that AVS allows identification of unilateral PA in patients presenting with $\mathrm{RH}$ and, more importantly, AVS-guided adrenalectomy effectively resolved RH in these patients.

In CHAPTER 3 we assessed the impact of surgery on health-related quality of life (QoL) and depression status of patients suffering from PA, which is associated with an increased prevalence of anxiety and depression.

Data on QoL and depression status were prospectively collected before, early after surgery (at 1 month) and at late follow up (at least 6 months) in patients with unilateral PA (n=26) and in a control group $(\mathrm{n}=15)$ with non-secreting adrenal tumors submitted to unilateral 
laparoscopic adrenalectomy. QoL was assessed using the Short Form 36 (SF-36) Health Survey for Physical (PCS) and Mental Component (MCS); the depression status by a 20item depression scale (DS) questionnaire. Biochemical cure of the disease was achieved following surgery in all PA patients; HT was cured in $31 \%$ of cases and improved in the remaining $69 \%$ of cases. No morbidity occurred in both groups. We found no significant differences between PA patients and controls concerning demographics, preoperative PCS, MCS and DS values. In patients with PA, MCS values improved at early (42.72 \pm 13.68 vs $51.56 \pm 9.03, \mathrm{p}=0.0005)$ and late follow up $(42.72 \pm 13.68$ vs $51.81 \pm 7.04, \mathrm{p}<0.0001)$; also DS values improved at early $(15.92 \pm 11.98$ vs $8.3 \pm 8.8, \mathrm{p}=0.0002)$ and late follow up $(15.92 \pm 11.98$ vs $4.57 \pm 6.11, \mathrm{p}<0.0001)$. In PA patients PCS values significantly improved at late follow up $(51.02 \pm 8.04$ vs 55.85 $\pm 5.1, \mathrm{p}=0.013)$. An improvement of MCS and DS scores was found at early and late follow-up also in controls, while no significant differences in PCS were found.

In CHAPTER 4 we introduce our main hypothesis that nonosmotic $\mathrm{Na}^{+}$storage has a significant impact on sodium and water homeostasis. We have proposed to use PA, a paradigm of salt-dependent low-renin HT and the most common cause of secondary HT, as a model to investigate the changes in skin- $\mathrm{Na}^{+}$content in HT. Our results show and confirm that $\mathrm{Na}^{+}$is stored in the skin of PA subjects without apparent accompanying water retention, proving the concept that a certain amount of $\mathrm{Na}^{+}$is inactive from a fluid balance view-point and implying that tissue-specific regulatory mechanisms might control the release and storage of $\mathrm{Na}^{+}$from a kidney-independent reservoir. More interestingly, skin$\mathrm{Na}^{+}$accumulation seems to be reversible after unilateral adrenalectomy but remains unchanged after medical treatment. Finally, skin- $\mathrm{Na}^{+}$content seems to be even higher in those PA patients who had a bilateral aldosterone hypersecretion, even if more data are needed to prove this evidence.

The present study includes also skin- $\mathrm{K}^{+}$data, which were not investigated so far. In this regard, skin- $\mathrm{K}^{+}$content seems to be similar in PA and in Controls; however, it increased significantly after adrenalectomy, suggesting a strict relation between serum $\mathrm{K}^{+}$and skin$\mathrm{K}^{+}$levels.

Based on these observations, we postulated that $\mathrm{Na}^{+}$can be "non-osmotically" stored in the skin while $\mathrm{K}^{+}$is "osmotically" regulated and influenced by water loss or retention. 
In CHAPTER 5 we present a protocol of a multicenter study, that will be carried out by the Universities of Maastricht, Padua, and Rome, aimed to analyze blood pressure variability (BPV) and skin electrolytes and water content in patients affected by fibromuscular dysplasia (FMD), a non-atherosclerotic, non-inflammatory angiopathy of unknown cause affecting medium-sized (most commonly renal 60-75\%) arteries. The hypothesis of the study is that renal FMD patients may have higher BPV markers compared to primary hypertensive subjects and that this finding might be correlate to the higher skinsodium and -water retention.

The study consists of two main phases. In the first part of the study, we have retrospectively compared BPV markers in FMD and essential hypertensive patients.

In the second part of the study a prospective analysis on BPV profile at baseline and after angioplasty, simultaneously to the collecting data on skin-sodium and water retention, will be performed. We will prospectively evaluate the differences in terms of $24 \mathrm{~h} \mathrm{ABPM}$ shortterm-derived BPV and skin-sodium and water content in skin biopsy, before and after specific renal artery revascularization. We will collect data on present and past medical history, current drug therapy, anthropometric evaluation (e.g. weight, height, waist circumference, BMI, systolic and diastolic blood pressure, etc.), 24-h ambulatory blood pressure monitoring, blood samples, [e.g. blood count, glycemia, lipid profile, plasma aldosterone concentration (PAC), direct renin (DRC), serum creatinine, serum ions ( $\mathrm{Na}+$, $\mathrm{K}+, \mathrm{Ca} 2+$ ), 24-h urinary albumin excretion (UAE)], and angio-CT scan measurements, such as stenosis percentage and kidneys diameters. During the renal angiography, in which the endoscopic revascularization will be performed, the first skin biopsy will be performed. At the follow-up evaluation, the anthropometric and BP values, including the BPV thought 24h ABPM, and the biochemical and hormonal profile after treatment will be analyzed. In this follow-up visit a second skin biopsy will be collected to examine the feasible reduction in sodium and water storage in the skin, due to the reduction of renin-angiotensinaldosterone system (RAAS) activity. As makers of hypertension-mediated organ damage we will use measurements of intima media thickness at Doppler ultrasonography study, the UAE, and the echocardiographic parameters, before and after renal revascularization.

The potential benefits of this study concern a better understanding of the cardiovascular risk profile and the physiopathological role of interstitial sodium in renal FMD hypertension, its correlation with organ damage and the development of new more rational and targeted treatments. 